\title{
INTRAPERSONAL INTELLIGENCE AND DECISION-MAKING Ability of Higher Secondary School Students
}

\author{
Pranab Barman (D) and Asim Roy (iD
}

The study aims to explore the level and relationship between intrapersonal intelligence and the decision-making ability of higher secondary school students. The study employed a survey-based quantitative method. The sample includes 500 higher secondary level school students in West Bengal, India. The investigators applied two self-made questionnaires, one for measuring intrapersonal intelligence and another for measuring decision-making ability. The results reveal that gender $(3.22, p<0.01)$ and stream $(4.05, p<0.001)$ have significant influences on the intrapersonal intelligence of the higher secondary school students. Decision-making Ability has a statistically significant and positive association with intrapersonal intelligence (0.42, $p<0.001)$. Results show that all the four dimensions of intrapersonal intelligence, i.e., self-awareness (2.871, $p<0.01)$, self-retrospection $(2.540, p<0.01)$, self-regard (5.265, $p<0.001)$, and self-adaptation (4.983, $p<0.001)$ significantly increase the decisionmaking ability of the higher secondary school students.

KEYWORDS: Intrapersonal Intelligence, DecisionMaking Ability, Higher Secondary School Students

\section{INTRODUCTION}

Man is the greatest creation of this universe. Man makes himself unique as compared to other animals by using his talent and intelligence. Since the beginning of the human civilization, man is able to solve his problems by applying his intelligence. Man takes various decisions and solves many problems of his life by applying his intelligence. The amount of intelligence may vary from man to man. 
Gardner has classified human intelligence into eight categories based on their special qualities in different aspects or areas of human endeavour. These are: (i) Linguistic/Verbal Intelligence, (ii) Spatial/Visual Intelligence, (iii) Bodily Kinaesthetic Intelligence, (iv) Musical Intelligence, (v) Mathematical/Logical Intelligence, (vi) Interpersonal Intelligence, (vii) Intrapersonal Intelligence and (viii) Naturalistic Intelligence Gardner (2011). Gardner in his theory of multiple intelligence very clearly explained that each and every category of intelligence helps us to do our specific functions. As for example, one can be a mathematician with his tremendous level of mathematical intelligence. On the other hand, one makes himself a musician because of his high level of musical intelligence Gardner (2011).

One of the most important but sometimes neglected categories of intelligence of Gardner's theory of multiple intelligence is intrapersonal intelligence. But this type of intelligence is very much needed for everyone. Because intrapersonal intelligence helps an individual to make his personal judgments about his own thoughts, emotions, strengths and weaknesses, to build appropriate mental models of themselves for making decisions about their own lives (González-Treviño, Núñez-Rocha, Valencia-Hernández, \& Arrona-Palacios, 2020; Mowat, 2011; Perez \& Ruz, 2014). Intrapersonal Intelligence comprises many unique aspects such as (i) awareness of self-feelings, (ii) awareness of self-strengths and weaknesses, (iii) self-understanding, (iv) self-confidence, (v) self-aspiration, (vi) ability of doing self-discipline, (vii) self-temperament, (viii) self-motivation as well as (ix) self-attention (Gardner, 2011) .

Intrapersonal intelligence is the ability to understand oneself, judging one's strengths and weaknesses, recognizing and controlling emotions, and the ability to solve conflicts between many things for getting psychological balance (Perez \& Ruz, 2014). Intrapersonal intelligence is the intelligence which is strongly associated with awareness and knowledge of oneself (Sholikhati, Mardiyana, \& Saputro, 2017). On the other hand, W. W. Tien and Chien (2001), Mowat (2011), and González-Treviño et al. (2020) stated that intrapersonal intelligence is ability to self-aware, self-examine, self-regard and self-adapt. In other words, it is said that intrapersonal intelligence is one kind of capacity for self-reflection which helps us to constitute our self-knowledge by judging our strengths and weaknesses, feelings, emotions and thought processes. Intrapersonal intelligence helps individuals to differentiate their emotions in order to build mental models of themselves while making decisions regarding their lives (Boo \& Kim, 2020; Chuang, Lee, \& Kwok, 2020; DiFabio \& Kenny, 2010; Storme, Celik, \& Myszkowski, 2017; Vertsberger \& Gati, 2015).

Gardner in his famous book 'Frames of Mind' described two intelligences 
as personal intelligence (Gardner, 2011). First one is interpersonal intelligence which is also called social intelligence. Second one is intrapersonal intelligence which comprises abilities like self-awareness and emotional expressiveness. He explained that children with high levels of intrapersonal intelligence know their emotions, strengths, and weaknesses very well, can easily interpret contradictory and complex emotions, and can exhibit their talents in many areas like creative writing and visual arts. These two types of intelligences are sometimes also called emotional intelligence (Goleman, 1995, 2000). On the other hand, W. Tien and Chien (2000) stated that intrapersonal, interpersonal, and interactive abilities are the basic elements of personal intelligence. Personal intelligence concerns with understanding about our own personality. It is concerned with some mental aspects and functions i.e., our motive, emotions, thoughts, knowledge, plan of action, self-awareness and self-control which are also related to our intrapersonal intelligence (J. Mayer, Caruso, \& Panter, 2019; J. D. Mayer, 2009).

It is said that for success in life it is very important for every person to take a right decision in right time. We must take decisions at every stage in our life. Our students are not exception in this regard. They have also to take many decisions regarding their academic life as well as their future career. But it is very difficult and problematic for our younger generation to take a right decision in a right time regarding their academic life and career also. For doing this task effectively, students must have adequate level of self-understanding, awareness about their strengths and weaknesses, power of controlling their emotions, good mission and vision, power of rational thinking, career Decision-Making self-efficacy, etc. In this regard, DiFabio, Palazzeschi, Asulin-Peretz, and Gati (2012) pointed out that career decision-making self-efficacy is a significant factor which affects our career decision-making process extensively. The career decision-making selfefficacy (CDMSE) helps to overcome the problem of career decision-making difficulties (CDD) as well as career indecision (Boo \& Kim, 2020; Chuang et al., 2020; Storme et al., 2017; Vertsberger \& Gati, 2015). In the same line, many studies reported a negative correlation between self-efficacy and indecision in career decision-making (Bullock-Yowell, Mcconnell, \& Schedin, 2014; Gadassi, Gati, \& Dayan, 2012; Gadassi, Gati, \& Wagman-Rolnick, 2013; Gati et al., 2010; Gati, Ryzhik, \& Vertsberger, 2013; Xu \& Tracey, 2015). Many scholars observed and explained that career confusion and career indecision is one of the most significant factors behind the student's decision to withdraw themselves from a college education (Hull-Blanks et al., 2005; Noel, Levitz, \& Saluri, 1986; Nutt, 2003).

Decision-Making is a process which is taken because of interaction between emotion and reason. It is observed through many research studies that emotions control our decision-making process. Negative emotions like stress, anx- 
iety, depression etc. adversely affect our decision-making process in operational context (Driskell \& Salas, 2016). Acht (2016) in his article reported that the few negative emotions like fear, anger, disgust and sadness had a very significant influence on the domains of judgments and choices which lead our decision-making process. Koshkaki and Solhi (2016) also reported that negative emotions significantly influence the decision-making behaviour. Sometimes the negative moods and emotions interferes our ability to process information. It is said that decisions taken by us being influenced by negative moods and emotions are mostly controlled by our mind, not by our heart. As a result, sometimes decisions may not be right as well as good for us (Bucurean, 2018). Therefore, it can be said that emotions can have a significant impact on Decision-Making process and solving a problem (Mulder, 2017). According to Goleman one of the most important components of emotional intelligence is intrapersonal understanding which encompasses many factors like emotional awareness, assertiveness, self-image, purposefulness, and independence. Independence means the ability to take decisions independently (Goleman, 1995).

Therefore, it is assumed that the strength and development of intrapersonal intelligence can be a vital factor in the selection of better career and future advancement. Because intrapersonal intelligence helps us to plan our future career clearly and decide accordingly. Gardner, in his theory of multiple intelligence stated that intrapersonal understanding is very essential element which helps an individual to judge his own strengths and weaknesses and take a decision effectively. Through the research studies it is found that the persons who have low self-understanding they are very confused about their career and suffering from indecision related problem. Many research findings showed that self-esteem, self-image and self-confidence of an individual can play a vital role in making a decision. All these aspects of an individual are closely related to his intrapersonal intelligence. In this regard, Gardner (2011) stated that having an accurate model of oneself is very much important for making a decision effectively. This is also an essential element of intrapersonal intelligence.

\section{ReView of Related Literature}

W. W. Tien (2001) conducted a study on 620 students regarding Conception and Appraisal of Personal Intelligence and explored that there was a statistically significant difference between boys and girl students with respect to their intrapersonal intelligence. The study showed that girls had comparatively more intrapersonal intelligence as compared to boys. Brown, GeorgeCurran, and Smith (2003) through their study explored that empathy, handling relationships, self-control, and utilization of feelings - all these factors of emotional intelligence were positively associated with career Decision-Making 
self-efficacy. The study also reported that the two factors i.e., Self-Control and Utilization of Feelings were inversely associated with vocational exploration and commitment.

Sevdalis, Petrides, and Harvey (2007) through their study also reported that trait Emotional Intelligence was positively associated with affective over prediction. Chauhan and Chauhan (2007) through their study revealed that a high level of emotional intelligence can have a positive contribution towards effective decision making. It was found that Decision-Making efficacy was positively correlated with emotional intelligence. Hess and Bacigalupo (2011) through their study explored that organizations as well as individuals may be benefitted from the development and utilization of behaviours ascribed to emotional intelligence. They reported that the practical application of the skills of emotional intelligence can enhance individual as well as group decisions and its outcomes.

DiFabio and Kenny (2010) observed through their study on Italian adolescents that the intervention related to development of emotional intelligence played a very significant role in fostering career Decision-Making process. In the same line, few research studies also explored that Decision-Making process is significantly associated with emotional intelligence (Brown et al., 2003; DiFabio \& Blustein, 2009; DiFabio \& Palazzeschi, 2009; Emmerling \& Cherniss, 2003). They reported that perceived indecisiveness and difficulties in making career decision is decreased by the emotional intelligence development related intervention. Puffer (2010)in his study on 561 college students reported that emotional intelligence is closely associated with career Decision-Making process. This study revealed that emotional intelligence can play a role as a salient predictor of vocational identity, vocational personality, and career indecision.

Through conducting a qualitative study of over 69 secondary school pupils, Mowat (2011) reported that intrapersonal intelligence plays a significant role in minimizing the social, emotional and behavioural difficulties that may be useful in Decision-Making process. Jiang (2014) in his one study showed that self-emotional appraisal (SEA), Others Emotional appraisal (OEA), Use of Emotion (UOE) and Regulation of Emotion (ROE) - all these four factors of emotional intelligence were positively associated with Career Decision-Making Self-Efficacy (CDMSE). Here SEA refers to individuals' ability to understand their own deep emotions. ROE denotes individual's ability which helps to regulate their own emotions and recover from psychological distress easily. And UOE is related to individuals' ability which helps to utilize their emotions to direct their personal performance and constructive activities. All these things are closely related to Intrapersonal Intelligence of a person. It was also explored that UOE can be the strongest factor of emotional intelligence in case of CDMSE because this factor helps students to 
understand of how to use their emotions to achieve goals and make a career decision effectively.

Jiang (2016) in another study also showed that emotional intelligence was positively associated with Career Decision-Making Self-Efficacy (CDMSE). This study suggested that increased Emotional Intelligence among university students can enhance their career decision-making confidence. Sumathy, Madhavi, and Felix (2015) conducted a study over 150 executive persons regarding their emotional intelligence and Decision-Making and they reported that emotional intelligence had a great influence in decision making. Especially, the empathy dimension of emotional intelligence had greatly influenced the decision-making process. On the other hand, Santos, Wang, and Lewis (2018) conducted a study on 472 university students of United Kingdom and showed in their study that emotional intelligence and career Decision-Making difficulties (CDD) were negatively interrelated with each other. It was also found in their study that career decision self-efficacy (CDSE) was positively related with emotional intelligence. Through this study, it was reported that emotional intelligence positively affects the students' career decision self-efficacy which can play as a potential mediator in the relationship between career decision-making difficulties (CDD) and emotional intelligence.

Kirdok and Korkmaz (2018) conducted a study on 432 high school students to explore the relationships among personality traits, emotional intelligence and career decision difficulties. The study explored that emotional instability was found to be a positive predictor of career decision difficulty. But on the other hand, self-awareness which is an essential component of emotional intelligence was negative predictors of career difficulty. It means that emotional intelligence can play a positive role in decision making. González-Treviño et al. (2020) conducted a study on 161 Mexican elementary school children (Boys-90 and Girls-71) and reported that there was a significant gender difference in respect to Intrapersonal Intelligence. They observed that boys reported higher scores in intrapersonal intelligence than that of the girls, which means that boys were more aware of their own behaviours and the consequences of their actions.

Although there are many studies found related to intelligence and decision making, but most of them have been conducted in relation to either emotional intelligence or personal intelligence or social intelligence. None of the studies found that has been conducted on Decision-Making ability in relation to intrapersonal intelligence particularly.

On the other hand, one of the most important and crucial stages of our academic life is the secondary stage of education. Here in this stage, students are facing lot of challenges about their academic as well as future career. One of the most vital challenges of the students at this stage is career confusion or 
career indecision (Inchara, Gayathri, \& Priya, 2019; Karacan-Ozdemir, 2019; Kirdok \& Korkmaz, 2018; Oztemel, 2013; Sharma, 2019) . Students start to prepare themselves for their future career at this stage. In a single word, it can be said that planning for future career of a student is started from this stage. But sometimes it is seen that most of the students are facing a common problem i.e., career indecision. Due to lack of experience and limitations, they can't be able to take a decision that is right and good for their future life (DiFabio \& Kenny, 2010; Kirdok \& Korkmaz, 2018; Leung, Hou, Gati, \& Li, 2011) . In this regard, it is very much necessary to understand oneself, one's weaknesses, strengths, limitations, emotions, etc. If one can understand about his/her weaknesses and strengths, then it is easy to make a decision for him.

Keeping in mind all these things, the investigators felt that this is a very important area where more and more research studies are needed to be carried out to explore in-depth results regarding intrapersonal intelligence and decision-making ability. And that's why the investigators have chosen this study.

\section{Objectives Of the Study}

The present study was conducted to:

(i) assess the level of intrapersonal intelligence and decision-making ability among the higher secondary school students in West Bengal, India.

(ii) find out the differences of students' intrapersonal intelligence with respect to gender, stream and school location.

(iii) examine the relationship between intrapersonal intelligence and decision-making ability among the higher secondary school students.

(iv) develop multiple regression equation to predict Decision-Making ability of higher secondary school students with the help of intrapersonal intelligence.

\section{Hypotheses Of the Study}

The study was conducted with following hypothetical considerations:

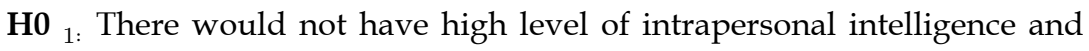
decision-making ability among the higher secondary school students in West Bengal.

$\mathbf{H O}_{2}$ : There is no significant difference among the students with respect to their intrapersonal Intelligence based on gender, stream, and school location. 
$\mathrm{HO}_{3:}$ There is no significant relationship between intrapersonal intelligence and decision-making ability among the higher secondary school students.

$\mathrm{HO}_{4}$ : It would not be possible to develop the regression equation to predict Decision-Making ability of higher secondary school students with the help of intrapersonal intelligence.

\section{PARTicipants AND Methods}

The present study was a survey based Quantitative study. The study was conducted on 500 students from the 16 (sixteen) selected higher secondary schools under the West Bengal council of higher secondary education situated in the districts of Hooghly and Purulia. The sample of the study has been selected using on stratified random sampling technique.

\section{RESEARCH ToOls Used}

For conducting the present study, the investigators applied two self-made questionnaires, one for measuring intrapersonal intelligence and another for measuring Decision-Making ability of the higher secondary school students.

\section{Intrapersonal Intelligence Scale (IIS)}

As there is no such scale found related to measuring intrapersonal intelligence of school students in Indian context particularly in Bengali Version, the investigators have tried to develop a scale by themselves to explore more prominent results. Before the construction of Intrapersonal Intelligence Scale, the present investigators surveyed few instruments related to this filed. The Personal Intelligence Inventory developed by W. Tien and Chien (2000) was one of the very relevant instruments for the present study. In the inventory three important facets namely interpersonal, intra-personal and interactive abilities were considered as measuring construct of personal intelligence. And in this inventory, intrapersonal abilities were measured by four important dimensions, i.e., self-awareness, self-retrospection, selfregard and self-adaptation (W. Tien \& Chien, 2000). By considering all these four dimensions, the present investigators developed a preliminary form of Intrapersonal Intelligence Scale based on Likert's five-point scale i.e., Strongly Agree $=5$, Agree $=4$, Neutral=3, Disagree $=2$, Strongly Disagree $=1$ (for Positive Items). Reverse scoring was assigned for negative items. Before finalizing the scale and its items, the investigators conducted a pilot study on a sample of 200 higher secondary level school students (who were not considered for final survey) for try out and item analysis. All the items were found to be significant at 0.01 level. 
The final scale was developed with the help of 36 Items which were distributed into four dimensions: i. Self-Awareness (6 Items), ii. SelfRetrospection (11 Items), iii. Self-Regard (10 Items), and iv. Self-Adaptation (9 Items). These four dimensions had been considered as measuring construct of intrapersonal intelligence of an individual (W. Tien \& Chien, 2000). In this scale, 21 Items were positive, and 15 Items were negative.

Self-Awareness (SA) is the ability or power or aptitude which helps an individual to become aware about his/her own feelings, emotions, strengths and weaknesses, discipline etc. Self-Retrospection (SRT) is the ability or power or aptitude by which an individual can examine/judge his/her own strengths and weaknesses, power of controlling his/her feelings and emotions. It helps to judge positive and negative aspects, success and failure before going to do a task. It is a capacity of self-reflection. Self-Regard (SR) is the ability which helps an individual to understand himself as what he/she is. It is one kind of self-image. Self-Adaptation (SAD) is the ability by which an individual can adjust or adapt with the environment or situation whatever it is. It helps to cope up with the any situation by controlling one's feelings and emotions. It is a technique of self-management or self-adjustment (W. Tien \& Chien, 2000).

For determining the internal consistency of the test items, the Cronbach Alpha was estimated. The estimated value of Cronbach's Alpha $(\alpha)$ for Intrapersonal Intelligence Scale was 0.84 which indicates good internal consistency of the tool, and it is considerable as well as acceptable in case of any intelligence test as stated by George and Mallery (2010); Lance, Butts, and Michels (2006); Nunnally (1978); Nunnally and Bernstein (1994); Singh (2009); Streiner, Norman, and Cairney (2015). And in case of measuring validity of the tool, expert judgment method was applied in the present study (Singh, 2009).

\section{Decision-Making Ability Questionnaire (DMAQ)}

The investigators developed another tool for measuring Decision-Making Ability. Before developing the Decision-Making Ability Scale, the investigators had gone through various instruments related to this field. In this regard, the investigators very carefully read the "Career Decision Self-Efficacy Scale-Short Form (CDSES-SF)" for college students developed by Betz, Klein, and Taylor (1996), "Decision-Making Questionnaire (DMQ)" developed by Lizarraga, Acedo, Baquedano, Oliver, and Closas (2009), “Decision-Making Competence (DMC)" tool for older adults developed by Finucane and Gullion (2010), "Managerial Decision-Making Self-Efficacy Questionnaire (MDMSEQ)" developed by Myburgh, Watson, and Foxcroft (2015), and "Melbourne Decision-Making Questionnaire (MDMQ)" developed by Cotrena, Branco, and Fonseca (2017). 
After going through all these tools, it was felt that there is a need to develop a decision-making ability questionnaire for secondary level school students in Bengali version as all the above mentioned tools were in English and none of them was for secondary school students. With the help of these tools, the present investigators constructed a preliminary form of Decision-Making Ability Questionnaire (DMAQ). This preliminary form of the questionnaire was administered on 200 higher secondary school students (who were not considered for final administration) for item analysis through a pilot study. After the pilot study, all the items were found to be significant at 0.01 level. This scale was constructed based on Likert's Five Point Scale i.e., Strongly Agree $=5$, Agree $=4$, Neutral $=3$, Disagree $=2$ and Strongly Disagree $=1$ (for Positive Items). In case of negative items, reverse scoring was calculated. The Decision-Making Ability Questionnaire (DMAQ) was constructed with the help of 25 Items, out of which 9 Items were positive and 16 items were negative. The value of Cronbach's Alpha $(\alpha)$ for Decision-Making Ability Questionnaire was 0.86 which can be considered acceptable for any research tool as suggested by George and Mallery (2010); Lance et al. (2006); Nunnally (1978); Nunnally and Bernstein (1994); Singh (2009); Streiner et al. (2015). The validity of Decision-Making Ability Questionnaire (DMAQ) was considered through expert judgment method in the present study Singh (2009).

In the present study intrapersonal intelligence, gender, location and stream have been treated as independent variable and on the other side DecisionMaking ability has been treated as dependent variable.

\section{Data Collection Procedure}

Before starting the data collection, the sixteen (16) schools were selected randomly under the West Bengal Council of Higher Secondary Education in the district of Hooghly and Purulia. After that the authorities and the concerned classes (XI \& XII) of each school were informed well in advance by the researchers for the purpose of data collection. The students were given clear instructions about the filling up of questionnaires before and during the process of data collection. Finally, 520 filled up questionnaires were collected through stratified random sampling method. But due to some problems of incompleteness, 20 questionnaires were rejected. After collecting and sorting the questionnaires, the researchers scored all the items of the questionnaires with the help of direct and reverse scoring method. The direct scoring method (5-4-3-2-1) was used in case of positive items and reverse scoring method (1-2-3-4-5) was used in case of negative items. 


\section{RESUlts AND INTERPRETATION}

The present study deals with intrapersonal intelligence and decision-making ability of higher secondary school students. So, what is the level of intrapersonal intelligence and decision-making ability? And how does intrapersonal intelligence influence Decision-Making ability of higher secondary school students? - questions to these answers are discussed hereunder.

Table 1

Demographic Profile of the Students (N=500).

\begin{tabular}{ll}
\hline Demographics & Number of Sample (\%) \\
\hline Age & \\
Age (16-18 Years) & $500(100 \%)$ \\
Gender & \\
Boys & $263(52.6 \%)$ \\
Girls & $237(47.4 \%)$ \\
Stream & \\
Arts & $250(50 \%)$ \\
Science & $250(50 \%)$ \\
School Location & \\
Rural & $260(52 \%)$ \\
Urban & $240(48 \%)$ \\
\hline
\end{tabular}

Table 1 shows the demographic profile of the sample. The age range of the students was 16-18 years. The study was conducted on $263(52.6 \%)$ boys and $237(47.4 \%)$ girls. The study also included stream and school location as demographic variables. There were $250(50 \%)$ arts and $250(50 \%)$ science stream students. On the other hand, $260(52 \%)$ rural and $240(48 \%)$ urban students were considered for conducting the study. 
Level of Intrapersonal Intelligence of Higher Secondary School Students

Table 2

Number, Mean and SD of Higher secondary school students on Intrapersonal Intelligence.

\begin{tabular}{llll}
\hline Group & Number & Mean & SD \\
\hline Students & 500 & $\mathbf{1 2 5 . 4 7}$ & $\mathbf{1 5 . 0 4}$ \\
\hline
\end{tabular}

$$
\begin{aligned}
& M \pm \sigma \\
& M+\sigma=125.47+15.04=140.51 \\
& M-\sigma=125.47-15.04=110.43
\end{aligned}
$$

To measure the level of intrapersonal intelligence of the students, the researchers applied the basic principles of Normal distribution Garrett (2007). On the basis of that the researchers applied the Formula $\mathrm{M} \pm \sigma$ (Table 2) and the scores obtained by the students on Intrapersonal Intelligence scale have been divided into three categories to explain the level of Intrapersonal Intelligence of the students. Here a score of above 140.51 denotes 'High', a score between 110.43 to 140.51 denotes 'Moderate' and a score of below 110.43 denotes 'Low'.

Table 3

Level of Intrapersonal Intelligence of Higher Secondary School Students on the basis of Cut-off Point.

\begin{tabular}{lccc}
\hline Scores & Frequency & Percentage & $\begin{array}{c}\text { Level of } \\
\text { Intrapersonal } \\
\text { Intelligence }\end{array}$ \\
\hline Above-140.51 & 79 & $15.8 \%$ & $\begin{array}{c}\text { High } \\
\text { Between-110.43 to }\end{array}$ \\
$\mathbf{1 4 0 . 5 1}$ & 328 & $65.6 \%$ & Moderate \\
Below-110.43 & 93 & $18.6 \%$ & Low \\
Total & $\mathbf{5 0 0}$ & $\mathbf{1 0 0} \%$ & \\
\hline
\end{tabular}

From Table 3, it can be seen that out of a total 500 Students, $15.8 \%$ Students have scored above $140.51,65.6 \%$ Students have scored between 110.43 to 140.51 and $18.6 \%$ Students have scored below 110.43 on intrapersonal intelligence measuring scale. Therefore, it can be said that the maximum percentage $(65.6 \%)$ of the higher secondary school students have scored between 110.43 to 
140.51, which indicates that the level of intrapersonal intelligence of the school going adolescents is moderate in the districts of Hooghly and Purulia, West Bengal.

Level of Decision-Making Ability of Higher Secondary School Students

Table 4

Number, Mean and SD of Higher Secondary School Students on Decision-Making Ability.

\begin{tabular}{llll}
\hline Group & Number & Mean & SD \\
\hline Students & 500 & 78.51 & 9.07 \\
\hline
\end{tabular}

$$
\begin{aligned}
& M \pm \sigma \\
& M+\sigma=78.51+9.07=87.58 \\
& M-\sigma=78.51-9.07=69.44
\end{aligned}
$$

Like intra-personal intelligence, the researchers also applied the basic principles of normal distribution in order to measure the level of decision-making ability of the students Garrett (2007). On the basis of this assumption the researchers applied the Formula $\mathrm{M} \pm \sigma$ (Table 4) and the scores obtained by the students on decision-making ability questionnaire have been divided into three categories to explain the level of Decision-Making ability of the students. Here a score of above 87.58 denotes 'High', a score between 69.44 to 87.58 denotes 'Moderate' and a score of below 69.44 denotes 'Low'.

Table 5

\begin{tabular}{|c|c|c|c|c|}
\hline Scores & & Frequency & Percentage & $\begin{array}{c}\text { Level of } \\
\text { Decision-Making } \\
\text { Ability }\end{array}$ \\
\hline Above- 87.58 & & 79 & $15.8 \%$ & High \\
\hline $\begin{array}{l}\text { Between-69.44 } \\
87.58\end{array}$ & to & 331 & $66.2 \%$ & Moderate \\
\hline Below-69.44 & & 90 & $18 \%$ & Low \\
\hline Total & & 500 & $100 \%$ & \\
\hline
\end{tabular}

Level of Decision-Making Ability of Higher Secondary School Students on the basis of Cut-off Point 
Intrapersonal Intelligence and Decision-Making Ability | 356

From Table 5, it can be seen that out of a total 500 students, $15.8 \%$ students have scored above $87.58,66.2 \%$ students have scored between 69.44 to 87.58 and $18 \%$ students have scored below 69.44 on Decision-Making Ability Scale. Therefore, it can be said that the maximum percentage $(66.2 \%)$ of the higher secondary school students have scored between 69.44 to 87.58 . This indicates that the level of Decision-Making Ability of the higher secondary school students is Moderate in the districts of Hooghly and Purulia, West Bengal.

Table 6

Results of t-Test Between Different Groups of Higher Secondary School Students on Intrapersonal Intelligence.

\begin{tabular}{|c|c|c|c|c|c|c|c|c|c|}
\hline Variables & Group & & $\mathbf{N}$ & Mean & SD & df & $\begin{array}{l}\text { Mean } \\
\text { Diff. }\end{array}$ & $\begin{array}{l}\mathbf{S} \\
E D\end{array}$ & $t$ \\
\hline Intrapersc & al Intel & ence & & & & & & & \\
\hline Condon & Boys & & 263 & 123.44 & 15.20 & & & & \\
\hline Gender & Girls & & 237 & 127.73 & 14.58 & 498 & 4.30 & 1.34 & $3.22^{* *}$ \\
\hline & Urban & School & 240 & 125.20 & 15.28 & & 053 & & \\
\hline & Studen & & & & & 498 & & 1.35 & 0.39 \\
\hline & $\begin{array}{l}\text { Rural } \\
\text { Studen }\end{array}$ & School & 260 & 125.73 & 14.87 & & & & \\
\hline tion & Urban & School & 135 & 123.59 & 14.17 & & & & \\
\hline of School & Boys & & & & & 238 & 3.67 & 1.98 & 1.86 \\
\hline & Urban & School & 105 & 127.27 & 16.43 & & & & \\
\hline & Girls & & & & & & & & \\
\hline & Rural & School & 128 & 123.27 & 16.28 & & 4.83 & & \\
\hline & Boys & & & & & 258 & & 1.82 & $2.65^{* *}$ \\
\hline & Rural & School & 132 & 128.11 & 12.98 & & & & \\
\hline & Girls & & & & & & & & \\
\hline & Urban & School & 135 & 123.59 & 14.17 & & 0.32 & & \\
\hline & Boys & & & & & 261 & 0.02 & 1.88 & 0.17 \\
\hline & Rural & School & 128 & 123.27 & 16.28 & & & & \\
\hline & Boys & & & & & & & & \\
\hline & Urban & School & 105 & 127.27 & 16.43 & & 004 & & \\
\hline & Girls & & & & & 235 & 0.84 & 1.91 & 0.44 \\
\hline & $\begin{array}{l}\text { Rural } \\
\text { Girls }\end{array}$ & School & 132 & 128.11 & 12.98 & & & & \\
\hline & Science & & 250 & 128.16 & 14.87 & & & & \\
\hline & Arts & & 250 & 122.79 & 14.78 & 498 & 5.36 & 1.33 & $4.05^{* *}$ \\
\hline & Scien & Boys & 122 & 126.35 & 15.50 & & $2=?$ & & \\
\hline & Scienc & Girls & 128 & 129.88 & 14.08 & 248 & 3.52 & 1.87 & 1.88 \\
\hline
\end{tabular}




\begin{tabular}{lllllllll}
\hline \multicolumn{1}{c}{ Table 6 continued } \\
\hline Arts Boys & 141 & 120.91 & 14.53 & \multirow{2}{*}{4.31} & & \\
Arts Girls & 109 & 125.22 & 14.82 & 248 & & 1.87 & $2.30^{*}$ \\
Science Boys & 122 & 126.35 & 15.53 & & 5.44 & & \\
Arts Boys & 141 & 120.91 & 14.53 & 261 & & 1.85 & $2.93^{* *}$ \\
Science Girls & 128 & 129.88 & 14.08 & & \multirow{2}{*}{4.65} & & \\
Arts Girls & 109 & 125.22 & 14.82 & 235 & & 1.88 & $2.48^{*}$ \\
\hline
\end{tabular}

*Significant at $0.05,{ }^{* *}$ Significant at 0.01

\section{Gender and Intrapersonal Intelligence}

From Table 6, we can see that the calculated ' $t$ '-value (3.22) is greater than the table value at both the levels of significance ( 0.05 and 0.01 level). Therefore, the result is significant, and it indicates that there was significant difference in students' intrapersonal intelligence based on gender. It can also be said that the girls have comparatively higher intrapersonal intelligence than the boys.

\section{School Location and Intrapersonal Intelligence}

Data in Table 6 shows that there is no statistically significant difference in students' intrapersonal intelligence based on school location as the calculated ' $t$ '-value (0.39) is less than the table value at 0.05 level of significance. However, a statistically significant difference was found between boys and girls of rural school with respect to their intrapersonal intelligence. Here, the calculated ' $t$ '-value (2.65) is greater than the table value at 0.05 level of significance. So, it can be inferred that girl students in the rural school have comparatively higher intrapersonal intelligence than the boys' students in the rural school.

\section{Stream and Intrapersonal Intelligence}

Results in Table 6, show that the calculated ' $t$ '-value (4.05) is greater than the table value at both the levels of significance. Therefore, it indicates that there is statistically significant difference between science and arts stream students with respect to their intrapersonal intelligence. It can also be said that the science stream students have comparatively high intrapersonal intelligence than the arts stream students. On the other hand, Boys and Girls Students in arts stream had significant differences with respect to their intrapersonal intelligence. In this case the calculated ' $t$ '-value (2.30) is greater than the table value at the 0.05 level of significance. It can also be said that Girl students in arts stream have comparatively high intrapersonal intelligence than the boys in the arts stream. Data also reveals that the ' $t$ '-value (2.93) is greater than the table value at both levels of significance in case of comparison between boys in science stream and boys in arts stream. The result indicated that the boys in science stream and boys in arts stream differed significantly with respect 
to their intrapersonal intelligence. Lastly, the results show that the calculated ' $t$ '-value (2.48) is greater than the table value at the 0.05 level of significance in case of comparison between girls in the science stream and arts stream. The result indicates that girls in science stream have a comparatively higher intrapersonal intelligence than the girls in arts stream.

\section{Table 7}

Relationship between the Different Dimensions of Intrapersonal Intelligence and Decision-Making Ability among the Higher Secondary School Students.

\begin{tabular}{|c|c|c|c|}
\hline Variables & & $\mathbf{r}$ & Interpretation \\
\hline \multirow{7}{*}{$\begin{array}{l}\text { Decision- } \\
\text { Making Ability }\end{array}$} & Intrapersonal Intel- & $0.42^{* *}$ & Moderate (Average) \\
\hline & ligence & & Positive Correlation \\
\hline & Self-Awareness & $0.33^{* *}$ & $\begin{array}{l}\text { Low Positive } \\
\text { Correlation }\end{array}$ \\
\hline & Self-Retrospection & $0.27^{* *}$ & $\begin{array}{l}\text { Low Positive } \\
\text { Correlation }\end{array}$ \\
\hline & Self-Regard & $0.42^{* *}$ & Moderate (Average) \\
\hline & & & Positive Correlation \\
\hline & Self-Adaptation & $0.36^{* *}$ & $\begin{array}{l}\text { Low Positive } \\
\text { Correlation }\end{array}$ \\
\hline
\end{tabular}

** Significant at 0.01

From Table 7, it can be seen that the calculated value of ' $r$ ' is 0.42 which is Significant at 0.01 level of Significance. The value shows moderate (average) positive correlation between intrapersonal intelligence and decision-making ability among the higher secondary school students. Hence, the Null Hypothesis is rejected, and it can be said that when one's intrapersonal intelligence will be high, the decision-making ability of that person will also be high.

To find out the relative contributions of different dimensions of Intrapersonal Intelligence to the dependent variable (Decision-Making Ability), multiple regression analysis has been successfully employed.

Table 8 shows the number of dependent and independent variables used for multiple regression analysis in the study. Each variable is presented here in this table with their abbreviated forms for the purpose of multiple regression analysis. The dependent variable'Decision-Making Ability' was abbreviated with 'DMA'. On the other hand, the four dimensions of independent variable 'Intrapersonal Intelligence' were abbreviated by 'SA', 'SRT', 'SR', and 'SAD' for 'Self-Awareness', 'Self-Retrospection', 'Self-Regard', and 'Self-Adaptation' respectively. 


\section{Table 8}

Shows the Dependent and Independent Variables used for Multiple Regression Analysis in the Present Study.

\begin{tabular}{lll}
\hline Variable No. & Description of the Variables & Symbol \\
\hline 1 & Decision-Making Ability & DMA \\
2 & Self-Awareness & SA \\
3 & Self-Retrospection & SRT \\
4 & Self-Regard & SR \\
5 & Self-Adaptation & SAD \\
\hline
\end{tabular}

Table 9

Value of R Square Estimated Through Multiple Regression Analysis.

\begin{tabular}{lcccc}
\hline $\begin{array}{l}\text { Model } \\
\text { Summary }\end{array}$ & & & \\
Model & R & R Square & Adjusted R Square & Std. Error \\
& & & \\
1 & $0.504^{a}$ & 0.254 & 0.248 & 7.877 \\
\hline
\end{tabular}

a. Dependent Variable: Decision-Making Ability (DMA)

b. Predictors: (Constant), SA, SRT, SR, SAD

\section{Regression Equation:}

$$
\mathrm{DMA}=42.007+0.295(\mathrm{SA})+0.163(\mathrm{SRT})+0.389(\mathrm{SR})+0.338(\mathrm{SAD})
$$

From Table 9, it can be seen that the $\mathrm{R}$ value indicates that the multiple correlation between the Decision-Making Ability (Dependent Variable) and the different aspects or dimensions of independent variable (Intrapersonal Intelligence) is 0.504 . The R-square figure indicates that approximately $25.4 \%$ of variance in decision-making ability can be explained by all the aspects or dimensions of independent variable (Intrapersonal Intelligence).

Out of the four dimensions of intrapersonal intelligence, the dimension of Self-Regard (SR) has a huge contribution to the dependent variable i.e., decision-making ability. The regression coefficient value $(0.248)$ shows that when this sub variable was included as predictor variable, then DecisionMaking ability would change or increases by 0.389 points for every unit of change in the dimension of Self-Regard (SR). The value of regression coefficient 
Table 10

Coefficient Values and t-values between Dependent Variables (DMA) and Four Dimensions of Independent Variable (Intrapersonal Intelligence).

\begin{tabular}{|c|c|c|c|c|c|c|}
\hline \multicolumn{7}{|c|}{ Coefficients ${ }^{a}$} \\
\hline \multirow[t]{2}{*}{ Model } & & \multicolumn{2}{|c|}{$\begin{array}{l}\text { Unstandardized } \\
\text { Coefficients }\end{array}$} & \multirow{2}{*}{$\begin{array}{c}\text { Standardized } \\
\text { Coefficients }\end{array}$} & \multirow[t]{2}{*}{$t$} & \multirow[t]{2}{*}{ Sig. } \\
\hline & & B & $\begin{array}{l}\text { Std. } \\
\text { Error }\end{array}$ & & & \\
\hline \multirow{5}{*}{1} & (Constant) & 42.007 & 2.992 & & $14.04^{* *}$ & .000 \\
\hline & SA & 0.295 & 0.103 & 0.130 & $2.87^{* *}$ & .004 \\
\hline & SRT & 0.163 & 0.064 & 0.107 & $2.54^{* *}$ & .011 \\
\hline & SR & 0.389 & 0.074 & 0.248 & $5.26^{* *}$ & .000 \\
\hline & SAD & 0.338 & 0.068 & 0.212 & $4.98^{* *}$ & .000 \\
\hline
\end{tabular}

**Sig. at 0.01 level, ${ }^{*}$ Sig. at 0.05 level

a. Dependent Variable: DMA

of Self-Regard (SR) was significant at 0.01 level (Table 10).

The second important dimension is Self-Adaptation (SAD) which has also a big contribution on the dependent variable. In case of this dimension, the regression coefficient value $(0.212)$ shows that when this sub variable was included as predictor variable, then Decision-Making Ability would change or increases by 0.338 points for every unit of change in the dimension of Self Adaptation (SAD). The value of regression coefficient of Self Adaptation (SAD) was significant at 0.01 level (Table-10).

The third important dimension is Self-Awareness (SA) which has also a big contribution on the dependent variable. In case of this dimension, the regression coefficient value ( 0.130 ) shows that when this sub variable was included as a predictor variable, then Decision-Making ability would change or increases by 0.295 points for every unit of change in the dimension of Self-Awareness (SA). The value of regression coefficient of Self-Awareness (SA) was significant at 0.01 level (Table 10).

The fourth dimension of intrapersonal intelligence i.e., Self-Retrospection (SRT) has also a significant contribution on the dependent variable. In case of this dimension, the regression coefficient value (0.107) shows that when this sub variable was included as predictor variable, then Decision-Making ability would change or increases by only 0.163 points for every unit of change in the 
dimension of Self-Retrospection (SRT). The value of regression coefficient of Self-Retrospection (SRT) was significant at 0.01 level (Table 10).

Therefore, from the above discussion a regression equation to predict the decision-making ability of higher secondary school students can be developed. The Regression Equation is:

\section{Decision-Making Ability $(\mathrm{DMA})=42.007+0.389(\mathrm{SR})+0.338(\mathrm{SAD})+$ 0.295 (SA) + 0.163 (SRT)}

From the above equation it is quite clear that the decision-making ability of higher secondary school students could be explained significantly with the help of four important dimensions or aspects of independent variable (intrapersonal intelligence), viz., Self-Regard (SR), Self-Adaptation (SAD), Self-Awareness and Self-Retrospection (SRT). Hence, the null hypothesis i.e., "It would not be possible to develop the regression equation to predict Decision-Making ability of higher secondary school students with the help of intrapersonal intelligence" stands rejected.

\section{Discussion AND CONCLUSION}

The results of the study showed that the higher secondary school students possessed moderate level of intrapersonal intelligence. This finding was supported by Carlin, Salazar, Cortes, and S (2013). Significant difference between Boys and Girls Students with respect to their Intrapersonal Intelligence were also observed. Results revealed that the girl students had comparatively high intrapersonal intelligence than the boys. This finding of the study was in line of the studies conducted by W. Tien and Chien (2000) and W. W. Tien (2001) as they reported that girls were more intelligent than the boys regarding intrapersonal domain. But this finding contradicts with the study conducted by González-Treviño et al. (2020). They observed that boys reported higher scores in intrapersonal intelligence than that of the girls. It was found that the rural school girls students had comparatively high intrapersonal intelligence than the rural school boys students. It was also found that the science stream students had comparatively high intrapersonal intelligence than the arts stream students. The girl students in the arts stream had comparatively high intrapersonal intelligence than the boys in arts stream. Results also show that the boys in the science stream had comparatively high intrapersonal intelligence than boys in the arts stream. It was also significantly revealed that the girl students in science stream had comparatively high intrapersonal intelligence than the girls in arts stream. All these were unique findings of the study. The results revealed that decision-making ability was significantly and positively $(0.42, \mathrm{p}<0.001)$ associated with intrapersonal intelligence as well as emotional intelligence. This finding of the study was supported by several 
studies (Brown et al., 2003; Chauhan \& Chauhan, 2007; DiFabio \& Blustein, 2009; DiFabio \& Kenny, 2010; DiFabio \& Palazzeschi, 2009; Emmerling \& Cherniss, 2003; Hess \& Bacigalupo, 2011; Jiang, 2014; Kirdok \& Korkmaz, 2018; Puffer, 2010; Santos et al., 2018). It was also found through the present study that all the four dimensions of intrapersonal intelligence, i.e., SA (2.871, $\mathrm{p}<0.01)$, SRT $(2.540, \mathrm{p}<0.01)$, SR (5.265, p<0.001), and SAD (4.983, $\mathrm{p}<0.001)$ had significant positive effects in increasing decision-making ability of higher secondary school students. These were unique findings of the present study in context of higher secondary school education and students too.

\section{REFERENCES}

Acht, C. (2016). The effect of negative emotions in decisions: A literature review (1sted.). GRIN Verlag.

Betz, N. E., Klein, K. L., \& Taylor, K. M. (1996). Evaluation of a Short Form of the Career Decision-Making Self-Efficacy Scale. Journal of Career Assessment, 4(1), 47-57. https:// doi.org/10.1177/106907279600400103

Boo, S., \& Kim, S. H. (2020). Career Indecision and Coping Strategies among Undergraduate Students. Journal of Hospitality $\mathcal{E}$ Tourism Education, 32(2), 63-76. https:// doi.org/10.1080/10963758.2020.1730860

Brown, C., George-Curran, R., \& Smith, M. L. (2003). The Role of Emotional Intelligence in the Career Commitment and Decision-Making Process. Journal of Career Assessment, 11(4), 379-392. https:// doi.org/10.1177/1069072703255834

Bucurean, M. (2018). The Effects of Moods and Emotions on Decision Making Process- A Qualitative Study. . Economic Sciences, 1(1), 423429.

Bullock-Yowell, E., Mcconnell, A. E., \& Schedin, E. A. (2014). Decided and Undecided Students: Career Self-efficacy, Negative Thinking, and Decision-Making Difficulties. NACADA Journal, 34(1), 22-34. https:// doi.org/10.12930/nacada-13-016

Carlin, R. E. T., Salazar, M. C., Cortes, C. V., \& S. (2013). A Mexican Study of Multiple Intelligences for Pre-Service Teachers of English as a Foreign Language. HOW, A Colombian Journal for Teachers of English, 20(1), 170-189. Retrieved from https://www.howjournalcolombia .org/index.php/how/article/view/29

Chauhan, S. P., \& Chauhan, D. (2007). Emotional Intelligence: Does It Influence Decision Making and Role Efficacy? Indian Journal of Industrial Relations, 43(2), 217-238.

Chuang, N. K., Lee, P. C., \& Kwok, L. (2020). Assisting students with career decision-making difficulties: Can career 
decision-making self-efficacy and career decision-making profile help. Journal of Hospitality, Leisure, Sport \& Tourism Education, 26. https:// doi.org/10.1016/j.jhlste.2019.100235

Cotrena, C., Branco, L. D., \& Fonseca, R. P. (2017). Adaptation and validation of the Melbourne Decision Making Questionnaire to Brazilian Portuguese. Trends in Psychiatry and Psychotherapy, 40(1), 29-37. https://doi.org/10.1590/2237-6089-2017-0062

DiFabio, A., \& Blustein, D. L. (2009). Emotional Intelligence and Decisional Conflict Styles: Some empirical evidence among Italian high school students. Journal of Career Assessment, 18(1), 71-81. https://doi.org/10.1177/1069072709350904

DiFabio, A., \& Kenny, M. E. (2010). Promoting Emotional Intelligence and Career Decision Making Among Italian High School Students. Journal of Career Assessment, 19(1), 21-34. https:// doi.org/10.1177/1069072710382530

DiFabio, A., \& Palazzeschi, L. (2009). Emotional intelligence, personality traits and career decision difficulties. International Journal for Educational and Vocational Guidance, 9(2), 135-146. https://doi.org/10.1007/s10775-009-9162-3

DiFabio, A., Palazzeschi, L., Asulin-Peretz, L., \& Gati, I. (2012). Career Indecision Versus Indecisiveness. Journal of Career Assessment, 21(1), 42-56. https://doi.org/10.1177/1069072712454698

Driskell, J. E., \& Salas, E. (2016). Stress and Human Performance. Psychology Press.

Emmerling, R. J., \& Cherniss, C. (2003). Emotional Intelligence and the Career Choice Process. Journal of Career Assessment, 11(2), 153-167.

Finucane, M. L., \& Gullion, C. M. (2010). Developing a tool for measuring the decision-making competence of older adults. Psychology and Aging, 25(2), 271-288. https://doi.org/10.1037/a0019106

Gadassi, R., Gati, I., \& Dayan, A. (2012). The adaptability of Career Decision-Making Profiles. Journal of Counseling Psychology, 59(4), 612-622. https://doi.org/10.1037/a0029155

Gadassi, R., Gati, I., \& Wagman-Rolnick, H. (2013). The Adaptability of Career Decision-Making Profiles. Journal of Career Development, 40(6), 490-507. https:// doi.org/10.1177/0894845312470027

Gardner, H. E. (2011). Frames of Mind: The Theory of Multiple Intelligences (3rd ed.). Basic Books.

Garrett, H. E. (2007). Statistics in psychology \& education. Paragon International Publishers.

Gati, I., Gadassi, R., Saka, N., Hadadi, Y., Ansenberg, N., Friedmann, R., \& Asulin-Peretz, L. (2010). Emotional and PersonalityRelated Aspects of Career Decision-Making Difficulties: Facets of Career Indecisiveness. Journal of Career Assessment, 19(1), 3-20. 
https:// doi.org/10.1177/1069072710382525

Gati, I., Ryzhik, T., \& Vertsberger, D. (2013). Preparing young veterans for civilian life: The effects of a workshop on career decision-making difficulties and self-efficacy. Journal of Vocational Behavior, 83(3), 373385. https:// doi.org/10.1016/j.jvb.2013.06.001

George, D., \& Mallery, P. (2010). Spss for windows step by step: A simple guide and reference 18.0 update (11th ed.) (and others, Ed.). Taylor \& Francis.

Goleman, D. (1995). Emotional intelligence: Why it can matter more than iq for character, health and lifelong achievement. Bantam Books.

Goleman, D. (2000). Working with emotional intelligence (reprint ed.). Bantam Books.

González-Treviño, I. M., Núñez-Rocha, G. M., Valencia-Hernández, J. M., \& Arrona-Palacios, A. (2020). Assessment of multiple intelligences in elementary school students in Mexico: An exploratory study. Heliyon, 6(4). https://doi.org/10.1016/j.heliyon.2020.e03777

Hess, J. D., \& Bacigalupo, A. C. (2011). Enhancing decisions and decision-making processes through the application of emotional intelligence skills. Management Decision, 49(5), 710-721. https:// doi.org/10.1108/00251741111130805

Hull-Blanks, E., Kurpius, S. E. R., Befort, C., Sollenberger, S., Nicpon, M. F., \& Huser, L. (2005). Career Goals and Retention-Related Factors Among College Freshmen. Journal of Career Development, 32(1), 16-30.

Inchara, R., Gayathri, R., \& Priya, V. V. (2019). Awareness on the choice of profession among school students - A survey. Drug Invention Today, 11(4), 871-874.

Jiang, Z. (2014). Emotional Intelligence and Career Decision-Making Self-Efficacy: National and Gender Differences. Journal of Employment Counseling, 51(3), 112-124. https://doi.org/10.1002/j.21611920.2014.00046.x

Jiang, Z. (2016). Emotional Intelligence and Career Decision-Making Self-Efficacy: Mediating Roles of Goal Commitment and Professional Commitment. Journal of Employment Counseling, 53(1), 30-47. https://doi.org/10.1002/joec.12026

Karacan-Ozdemir, N. (2019). Associations between career adaptability and career decision-making difficulties among Turkish high school students. International Journal for Educational and Vocational Guidance, 19(3), 475-495. https://doi.org/10.1007/s10775-019-09389-0

Kirdok, O., \& Korkmaz, O. (2018). Dimensions of personality and emotional intelligence as predictors of high school students' career decision difficulties. Educational Research and Reviews, 13(12), 495-502. https:/ / doi.org/10.5897/ERR2018.3532

Koshkaki, E. R., \& Solhi, S. (2016). The facilitating role of negative emotion in decision making process: A hierarchy of effects model approach. 
The Journal of High Technology Management Research, 27(2), 119-128. https:// doi.org/10.1016/j.hitech.2016.10.010

Lance, C. E., Butts, M. M., \& Michels, L. C. (2006). The Sources of Four Commonly Reported Cutoff Criteria. Organizational Research Methods, 9(2), 202-220. https:// doi.org/10.1177/1094428105284919

Leung, S. A., Hou, Z. J., Gati, I., \& Li, X. (2011). Effects of parental expectations and cultural-values orientation on career decision-making difficulties of Chinese University students. Journal of Vocational Behavior, 78(1), 11-20. https://doi.org/10.1016/j.jvb.2010.08.004

Lizarraga, M. L. S. D. A., Acedo, S. D., Baquedano, M. T., Oliver, M. S., \& Closas, A. (2009). Development and validation of a decision-making questionnaire. British Journal of Guidance \& Counselling, 37(3), 357-373. https:// doi.org/10.1080/03069880902956959

Mayer, J., Caruso, D., \& Panter, A. (2019). Advancing the Measurement of Personal Intelligence with the Test of Personal Intelligence, Version 5 (TOPI 5). Journal of Intelligence, 7(1), 4. https:// doi.org/10.3390/jintelligence7010004

Mayer, J. D. (2009). Personal Intelligence Expressed: A Theoretical Analysis. Review of General Psychology, 13(1), 46-58. https://doi.org/10.1037/a0014229

Mowat, J. G. (2011). The development of intrapersonal intelligence in pupils experiencing social, emotional and behavioural difficulties. Educational Psychology in Practice, 27(3), 227-253. https:// doi.org/10.1080/02667363.2011.603531

Mulder, P. (2017). Emotional Intelligence Components. Retrieved 202009-20, from https://www.toolshero.com/personal-development/ emotional-intelligence-components/

Myburgh, W., Watson, M. B., \& Foxcroft, C. D. (2015). Development and validation of a managerial decision-making selfefficacy questionnaire. SA Journal of Industrial Psychology, 41(1). https:// doi.org/10.4102/sajip.v41i1.1218

Noel, L., Levitz, R., \& Saluri, D. (1986). Increasing Student Retention: Effective Programs and Practices for Reducing the Dropout Rate. Adult Education Series.

Nunnally, J. C. (1978). Psychometric theory. Mcgraw-Hill College.

Nunnally, J. C., \& Bernstein, I. H. (1994). Psychometric theory (3rd ed.). McGraw-Hill.

Nutt, C. L. (2003). Retrieved from https://nacada.ksu.edu/Resources/ Academic-Advising-Today/View-Articles/Student-Retention-and -Persistence.aspx

Oztemel, K. (2013). An Investigation of Career Indecision Level of High School Students: Relationships with Personal Indecisiveness and Anxiety. The Online Journal of Counseling and Education, 2(3), 46-58. 
Perez, M. D. M. P., \& Ruz, N. R. (2014). Intrapersonal Intelligence and Motivation in Foreign Language Learning. European Scientific Journal, 10(17), 142-150.

Puffer, K. A. (2010). Emotional Intelligence as a Salient Predictor for Collegians' Career Decision Making. Journal of Career Assessment, 19(2), 130-150. https://doi.org/10.1177/1069072710385545

Santos, A., Wang, W., \& Lewis, J. (2018). Emotional intelligence and career decision-making difficulties: The mediating role of career decision self-efficacy. Journal of Vocational Behavior, 107, 295-309. https:// doi.org/10.1016/j.jvb.2018.05.008

Sevdalis, N., Petrides, K., \& Harvey, N. (2007). Trait emotional intelligence and decision-related emotions. Personality and Individual Differences, 42(7), 1347-1358. https://doi.org/10.1016/j.paid.2006.10.012

Sharma, R. (2019). Career Indecision among undergraduate students in India. Research Journal of Humanities and Social Sciences, 10(1), 68-72. https:// doi.org/10.5958/2321-5828.2019.00012.3

Sholikhati, R., Mardiyana, \& Saputro, D. R. S. (2017). Students' thinking level based on intrapersonal intelligence. Journal of Physics: Conference Series, 943. https:// doi.org/10.1088/1742-6596/943/1/012007

Singh, A. K. (2009). Tests, measurements and research methods in behavioural sciences. New Delhi: Bharati Bhawan.

Storme, M., Celik, P., \& Myszkowski, N. (2017). Career Decision Ambiguity Tolerance and Career Decision-Making Difficulties in a French Sample: The Mediating Role of Career Decision Self-Efficacy. Journal of Career Assessment, 27(2), 273-288. https://doi.org/10.1177/1069072717748958

Streiner, D. L., Norman, G. R., \& Cairney, J. (2015). Health measurement scales (and others, Ed.). Oxford Medicine Online. https:// doi.org/10.1093/med/9780199685219.001.0001

Sumathy, L., Madhavi, C. A., \& Felix, J. W. (2015). Influence of Emotional Intelligence on Decision Making by Leaders. American International Journal of Social Science, 4(1), 134-140.

Tien, W., \& Chien, W. (2000). Conception and appraisal of personal intelligence. Bulletin of Special Education, 18, 237-255.

Tien, W. W. (2001). Conception and Appraisal of Personal Intelligence - Projects. Child Research Net. Retrieved from https://www .childresearch.net/projects/special/2001_01.html

Tien, W. W., \& Chien, M. F. (2001). The effect of personal intelligence-focused multiple intelligences curriculum on elementary school students' personal growth and coping behaviors. Journal of Gifted Education, 1(1), 1-28.

Vertsberger, D., \& Gati, I. (2015). Career Decision-Making Difficulties and Help-Seeking Among Israeli Young Adults. Journal of Career Devel- 
367 | Pranab Barman and Asim Roy

opment, 43(2), 145-159. https:// doi.org/10.1177/0894845315584162

$\mathrm{Xu}, \mathrm{H}$., \& Tracey, T. J. (2015). Ambiguity tolerance with career indecision: An examination of the mediation effect of career decision-making self-efficacy. Journal of Career Assessment, 23(4), 519-532. https://doi.org/10.1177/1069072714553073 